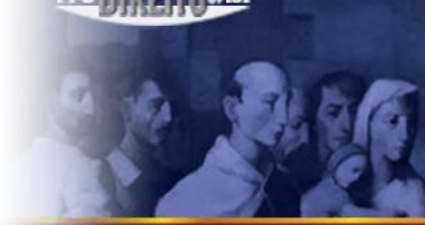

\title{
DIREITOS E DEVERES DOS ESTADOS-MEMBROS: EFEITOS DECORRENTES DA APLICAÇÃO DO MECANISMO DE SUSPENSÃO NO MERCOSUL
}

\author{
RIGHTS AND DUTIES OF MEMBER-STATES: EFFECTS OF THE APPLICATION OF THE \\ SUSPENSION MECHANISM IN THE MERCOSUR
}

Andréa Rocha Postiga*

\begin{abstract}
RESUMO: Violações de direitos humanos por parte de um Estado revelam-se incompatíveis com sua participação em qualquer processo de integração. A preservação dos direitos humanos deve desempenhar papel central no bojo de um processo integracionista, constituindo inclusive pressuposto para o seu ingresso em blocos regionais. Esse assunto já relevante teve acentuada sua importância pelos recentes acontecimentos que tiveram lugar nos me-ses de junho e julho de 2012 no âmbito do Mercosul. O presente estudo analisa a proteção desses direitos e princípios por meio do mecanismo da suspensão do Estado que viola os valores fundamentais dos blocos regionais, identificando as peculiaridades inerentes ao caso do Mercosul. Na primeira parte, examina-se o marco jurídico adotado pelo Mercosul para suspensão de um Estado-membro do bloco em caso de violação destes princípios e direitos, e as peculiaridades a ele inerentes. No segundo momento, parte-se para o estudo dos recentes episódios da suspensão do Paraguai em julho de 2012, como forma de repressão à alegada ruptura da ordem democrática naquele país, e da concomitante adesão da Venezuela ao bloco. Pondera-se a adequação jurídica e fática dos mecanismos empregues para determinar a extensão dos efeitos práticos e jurídicos decor-rentes dos eventos ocorridos no âmbito do bloco.
\end{abstract}

PALAVRAS-CHAVE: Mercosul; Integração regional; Democracia; Suspensão; Direitos humanos.

SUMÁRIO: Introdução. 1. Estado-parte e compromisso democrático: a preservação da ordem democrática como pressuposto da confiança mútua entre os Estados. 2. Processo sancionatório do Paraguai como fator de dispersão no Mercosul. Considerações finais. Referências.

\section{INTRODUÇÃO}

A evolução da cultura jurídica no bojo dos valores democráticos demonstrou que a organização atual dos Estados não deve admitir, em qualquer hipótese, violações de direitos humanos. No bojo dos blocos regionais a mesma intolerância se reproduz, por se tratar de prática incompatível com a participação de um Estado em um processo de integração (BORGES, 2009, p. 327).

\footnotetext{
* Mestre em Direito Internacional pela Universidade Federal do Rio Grande do Sul (UFRGS).
}

KEYWORDS: Mercosur; Regional integration; Democracy; Suspension; Human rights. 


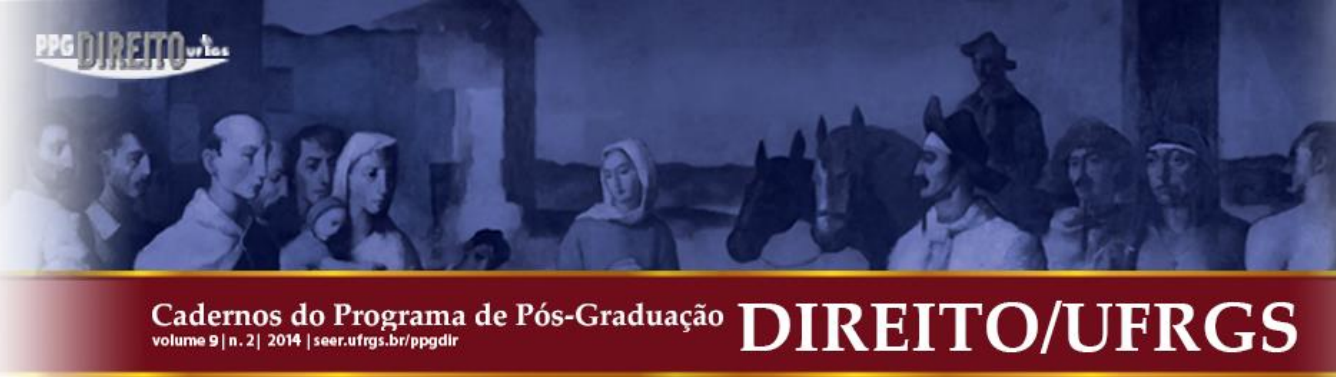

A responsabilidade internacional e comunitária é imputável ao ato ilícito respectivo. Não se trata de um direito cogente, mas dispositivo, que vai gradativamente saturando-se de sanções coativas nas relações interestatais. Na condição de um dos pilares do regime democrático, é altamente desejável que a evolução do direito interestatal venha a considerar a salvaguarda dos direitos humanos como pressuposto para o ingresso de Estados em blocos regionais.

A ligação entre a democracia e esta proteção fica evidenciada no melhor exemplo de integração regional até o momento, a União Europeia: a pretensão de um Estado não democrático e violador dos direitos humanos é incompatível com sua inserção no espaço comunitário, não só porque estaria a violar o Tratado da União Europeia e os princípios de Direito Internacional, mas também porque ausentes os pressupostos para a consolidação da confiança mútua entre os Estados membros do bloco (BORGES, 2009, p. 327).

No Mercosul, bloco essencialmente de fins econômicos (se não exclusivamente), a proteção interestatal dos direitos humanos estaria situada fora do âmbito de atuação do bloco. Seu caráter "essencialmente econômico" suscita controvérsias devido à inserção de determinados assuntos no preâmbulo do Tratado de Assunção, tais como o objetivo de proteção do meio ambiente. Já a proteção da democracia vem salvaguardada em protocolo adicional, firmado sete anos após a formação do bloco, e vigente há pouco mais de 9 anos.

Nesse contexto, a preservação da democracia e o fortalecimento do regime democrático devem embasar a preservação de todo rol de direitos. Tal dever assume contornos jurídicos tão logo é instituído, sobretudo nos tratados internacionais. É o que se depreende por força das disposições constantes dos tratados regionais. O processo unificador europeu teve como objetivo a manutenção da paz. No caso do Mercosul, a manutenção e estabilização dos regimes democráticos foi a grande conquista alcançada com sua criação. Hoje as liberdades fundamentais garantidas constitucionalmente nos Estados-parte não mais condizem com a forma totalitária de regime.

A formação de um mercado comum ou de qualquer organização, seja seu caráter internacional ou supraestatal, pressupõe que seus membros se pautem por estes princípios e que incluam dentre seus objetivos a preservação e a proteção desses direitos em suas relações. Visando garantir seu respeito e proteção por parte dos Estados-membros, foram incluídos mecanismos de proteção desses direitos na esfera regional do Mercosul, a serem apreciados neste estudo. A forma como esta proteção foi desenhada diverge um pouco do modelo europeu, 


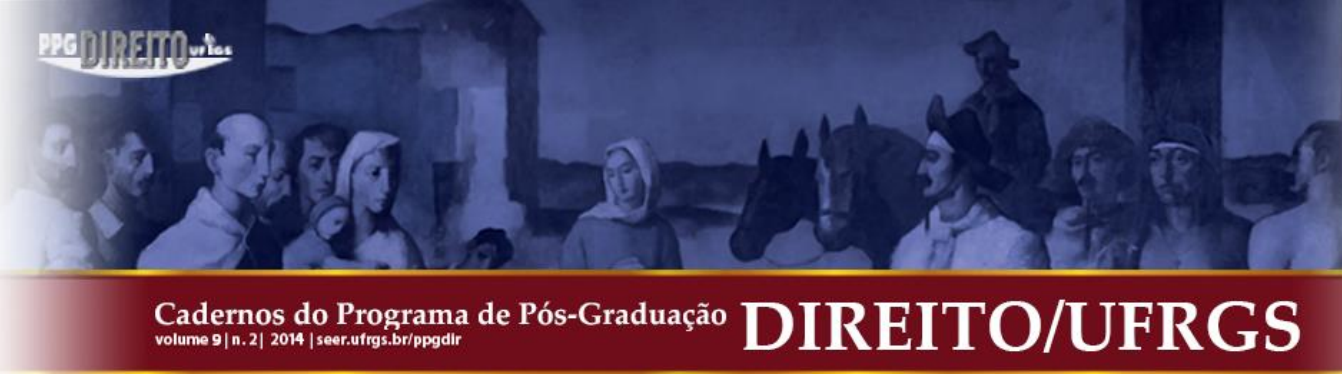

sobretudo em razão dos propósitos para os quais cada organização foi criada. Em ambos os casos, porém, concorda-se que, sem tais recursos, a confiança recíproca entre os Estados fica prejudicada, quiçá impedida.

Reconhecida a relevância do tema para a integração regional, o presente estudo analisa os recentes acontecimentos que tiveram lugar no Mercosul nos meses de junho e julho de 2012, que suscitaram inúmeras controvérsias acerca da legitimidade e propriedade dos procedimentos adotados pelo bloco na ocasião. Para tanto, na primeira parte o foco do exame será o estudo do marco jurídico que regula a suspensão de um Estado-membro do Mercosul. No segundo momento, será dada especial atenção ao recente episódio da suspensão do Paraguai, como forma de repressão à alegada ruptura da ordem democrática naquele país, em razão dos acontecimentos que tiveram lugar no mês de julho de 2012.

O estudo em conjunto de situação ocorrida paralelamente à suspensão do Paraguai, qual seja a de adesão da Venezuela ao bloco, está diretamente relacionado ao assunto, integrando igualmente a presente análise. Pondera-se, neste estudo, a adequação jurídica e fática do mecanismo empregue para a suspensão do Estado-parte à busca dos objetivos visados pelo bloco. Busca-se, para esta compreensão, determinar a correta extensão dos efeitos práticos e jurídicos decorrentes desta suspensão no âmbito das relações do bloco.

\section{ESTADO-PARTE E COMPROMISSO DEMOCRÁTICO: A PRESERVAÇÃO DA ORDEM DEMOCRÁTICA COMO PRESSUPOSTO DA CONFIANÇA MÚTUA EN- TRE OS ESTADOS}

O Tratado de Assunção, documento de base do bloco do Mercosul, traz no bojo de seu artigo $1^{\circ}$ os princípios fundamentais que informam o bloco, sendo estes a livre circulação de bens, de serviços e de fatores produtivos entre os países que o integram, o que deve ser obtido com a eliminação de direitos aduaneiros, entre outros, e restrições não tarifárias à circulação de mercadorias e qualquer medida de efeito equivalente, sendo estabelecida uma tarifa externa comum e adotada também política comercial comum em relação a Estados terceiros. A coordenação de políticas macroeconômicas e setoriais entre as partes e o compromisso de harmonizarem suas legislações nas áreas pertinentes para o fortalecimento do processo integracionista figuravam igualmente neste rol (BERNALETTE, 2012, p. 8). 


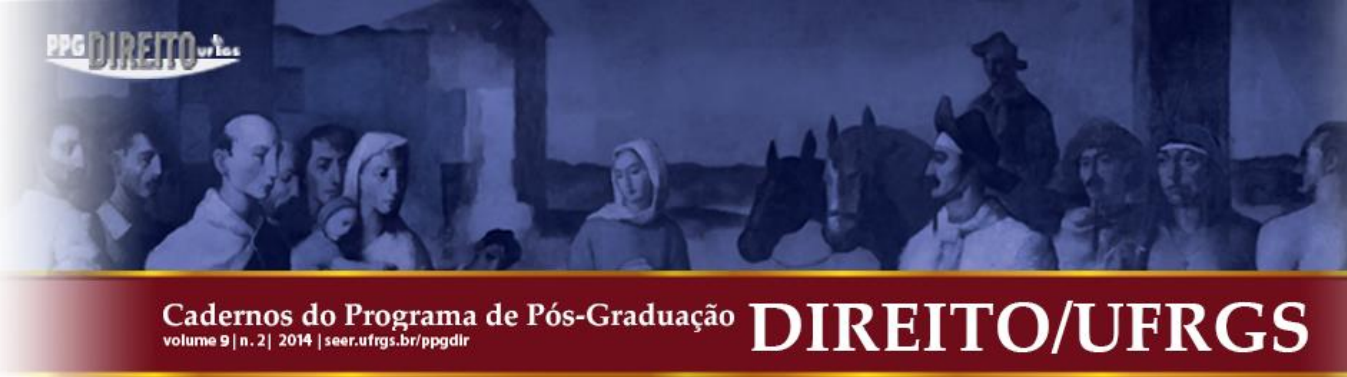

Esses princípios fundamentais, pelo seu âmbito espacial interestatal de validade, constituem uma característica que autonomiza a ordem interna do Mercosul, diante da ordem internacional e das ordens nacionais. $\mathrm{O}$ artigo $2^{\circ}$, do Tratado de Assunção, consagra o princípio da reciprocidade, segundo o qual "[o] mercado comum estará fundado na reciprocidade de direitos e obrigações entre os Estados-parte". As liberdades previstas são instrumentais da democracia nas relações tecidas.

Embora todos os Estados-partes do Mercosul já compartilhassem dos valores democráticos, por meio da forma de governo, à época da celebração do Tratado de Assunção, em 1991, não foi incluída no corpo do Tratado uma cláusula democrática de forma específica (HOFFMANN, 2009, p. 343). Entretanto, já em 1992, na Declaração Presidencial da Segunda Cúpula Presidencial do Mercosul, os chefes de Estado do bloco consagram, no parágrafo 2, a plena vigência das instituições democráticas como pressuposto indispensável para existência e para o desenvolvimento do Mercosul (MERCOSUL, 2012).

Assim, a confiança recíproca entre os Estados do Mercosul deve se apoiar sobre o conteúdo material da democracia, que está materialmente fixado no corpo das constituições destes Estados. Quebrados esses pressupostos, providências serão tomadas.

Como ensina Jamile Bergamaschine Mata Diz, a suspensão temporária no Mercosul teria como fundamento o desrespeito ao regime democrático que deveria imperar na região, condição para ingresso e permanência no bloco. A condicionalidade democrática foi formalmente incorporada ao tratado de Assunção por meio do protocolo de Ushuaia, assinado em 1998, em vigor desde janeiro de 2002 (HOFFMANN, 2009, p. 344). O artigo $1^{\circ}$ do referido documento figura como eixo central da proteção da ordem democrática no Mercosul (MATA DIZ, 2012, pp. 4-6).

O Protocolo representou a consolidação normativa da Decisão Presidencial sobre o Compromisso Democrático dos países do Mercosul (Declaração de San Luis), de junho de 1996, emitida pouco mais de um mês após uma tentativa de golpe de Estado no Paraguai, reiterando este princípio central e estabelecendo oficialmente a cláusula democrática do bloco, constituindo igualmente a materialização das disposições constantes do Tratado de Assunção em seu preâmbulo e nos artigos $1^{\circ}$ e 20 (STURARO, 2012, pp. 46-47).

Consolidando o entendimento consagrado nos tratados, Patrícia Kegel lembra que a integração que não se funda sobre os pilares do Estado democrático de direito não é viável. O respeito aos direitos humanos e a consagração nas Cartas Constitucionais destes pilares são 


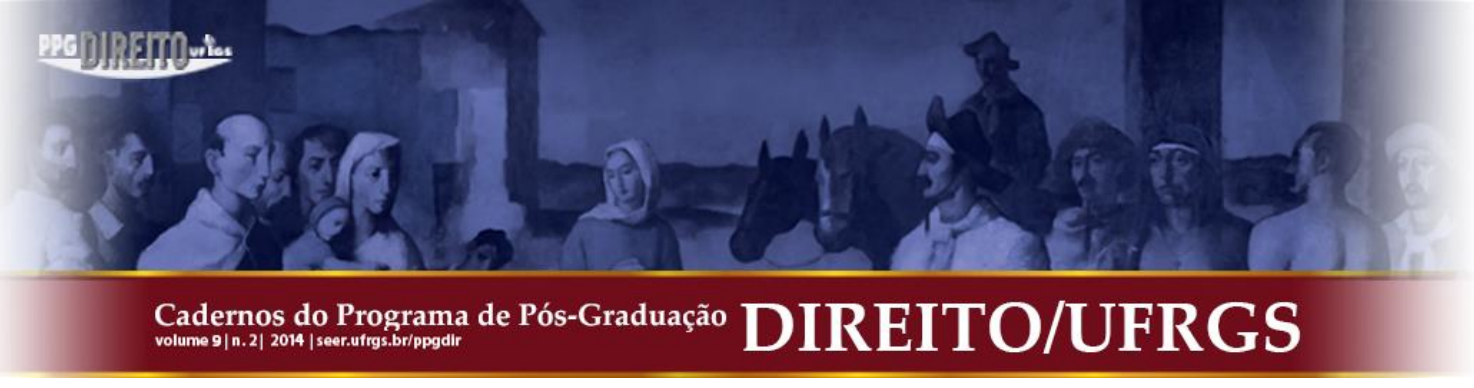

pressuposto para uma ordem democrática e, portanto, para uma integração regional saudável (KEGEL, 2012).

Assim, quando detectada qualquer prática caracterizadora de ruptura com a ordem democrática, será seguido o procedimento previsto no Protocolo de Ushuaia sobre Compromisso Democrático no Mercosul, Bolívia e Chile. No Mercosul, contudo, não existe mecanismo preventivo, como há na União Europeia, podendo a cláusula democrática somente ser acionada quando detectada efetiva ruptura da ordem democrática (HOFFMANN, 2009, p. 343).

$\mathrm{O}$ instrumento prevê, em seu artigo $4^{\circ}$, que antes da tomada de quaisquer providências, detectada a ruptura em um Estado-parte, os demais deverão promover consultas pertinentes entre si e com o Estado afetado, como etapa preliminar. Entretanto, cabe aqui anotar que não é precisa e objetiva a definição e a extensão do conceito de "ruptura democrática", fato essencial para a tomada de providencias contra um Estado e que depende de consensos políticos a respeito de definições de democracia e de ruptura com a ordem democrática (HOFFMANN, 2009, p. 343). Esta questão suscitou amplo debate em torno dos recentes acontecimentos no âmbito do bloco, como será estudado no curso deste ensaio.

O procedimento do artigo $5^{\circ}$ é posto em prática: dispõe que, infrutíferas as consultas, os Estados-parte decidirão a natureza e o alcance das medidas a serem aplicadas, a partir da análise da gravidade da situação existente. Assim, de acordo com o dispositivo, a sanção variará entre a suspensão do direito de participar nos órgãos dos respectivos processos de integração até a suspensão dos direitos e obrigações destes resultantes. As medidas serão tomadas por consenso entre os Estados-partes, assim como as demais decisões, e serão comunicadas ao Estado afetado, que não participa deste processo decisório, durando até que estes entendam que houve o restabelecimento pleno da ordem democrática (MERCOSUL, 1998).

No que toca à fixação do "quantum" da sanção, o texto não apresenta clareza quanto aos critérios a serem empregues, mas se depreende da leitura que variarão conforme a avaliação dos Estados-partes acerca da gravidade da ruptura ocorrida. Tal exprime, em última análise, um julgamento de ordem essencialmente política, e não jurídica, espelhando a concepção adotada na União Europeia. Cessará a suspensão quando os representantes dos Estados reconhecerem que a ordem democrática foi restaurada (MERCOSUL, 2012).

Aprofundando os termos da proteção dispensada, em 2005 foi assinado o Protocolo de Assunção sobre Compromisso com a Promoção e Proteção dos Direitos Humanos, documento que ampliou o escopo normativo da cláusula democrática para incluir o respeito aos direitos 


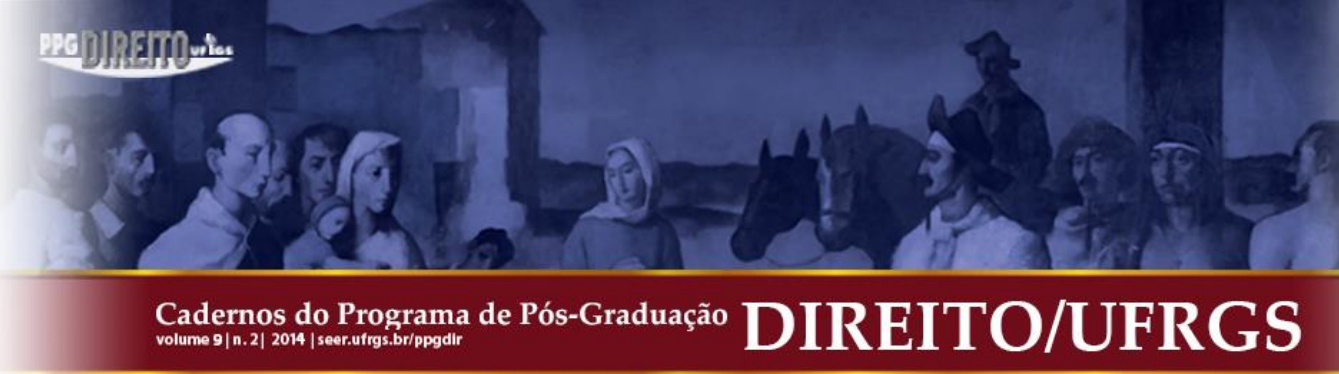

humanos e às liberdades fundamentais como condições essenciais à vigência e à evolução do processo integracionista.

O conteúdo normativo do Protocolo sofreu alterações em suas regras e no procedimento de tomada de decisão em dezembro de 2011, por meio do Protocolo de Montevideo sobre Compromisso com a Democracia no Mercosul, também conhecido como Ushuaia II. No entanto, tal documento ainda não entrou em vigor, tendo em vista que depende ainda da ratificação de todos os Estados-parte, o que ainda não ocorreu.

Deste modo, o processo de suspensão de um Estado-parte do Mercosul encontra respaldo e previsão na lei fundamental do bloco, o Tratado de Assunção (1991), no Protocolo de Ushuaia, que regula o procedimento, e também no Protocolo de Olivos, que rege o funcionamento do Tribunal Permanente de Revisão, e o Protocolo de Ouro Preto, todos integrando o texto do Tratado de Assunção.

Recentemente o Mercosul vivenciou um episódio concreto de suspensão de um de seus Estados-partes, o Paraguai, que, desde o final de junho de 2012, por decisão dos líderes políticos da região, sofre os efeitos decorrentes da pena de suspensão aplicada. Para os chefes de Estado, houve rompimento da ordem democrática na forma como se procedeu o impeachment do então presidente Fernando Lugo. Questionou-se o ato, pois Lugo foi submetido a um processo de impeachment que durou menos de 24 horas. As autoridades paraguaias, por seu turno, negam o desrespeito da ordem democrática, afirmando que o procedimento seguido teria recebido integral amparo da Carta Constitucional paraguaia, acrescentando inclusive que a Lugo teria efetivamente sido concedido o exercício da ampla defesa, dentro das condições previstas na legislação pátria.

O secretário-geral da Organização dos Estados Americanos (OEA), José Miguel Insulza, questionou o processo que levou ao impeachment do ex-presidente do Paraguai, em menos de 24 horas (UCHOA, 2012). Lugo foi retirado do poder em votação no Senado em 22 de junho, como resultado de uma crise política iniciada com a morte de 17 pessoas em confrontos entre policiais e sem-terra durante uma ação de reintegração de posse. O processo de impeachment durou apenas pouco mais de 24 horas e foi duramente criticado pelo próprio Lugo, que afirmou que o processo era inconstitucional, e pela comunidade internacional (BBC Brasil, 2012).

A partir da análise do conjunto, cabe aqui ressaltar que a adesão de novos Estados constitui uma das manifestações fundamentais da capacidade jurídica internacional de toda Orga- 


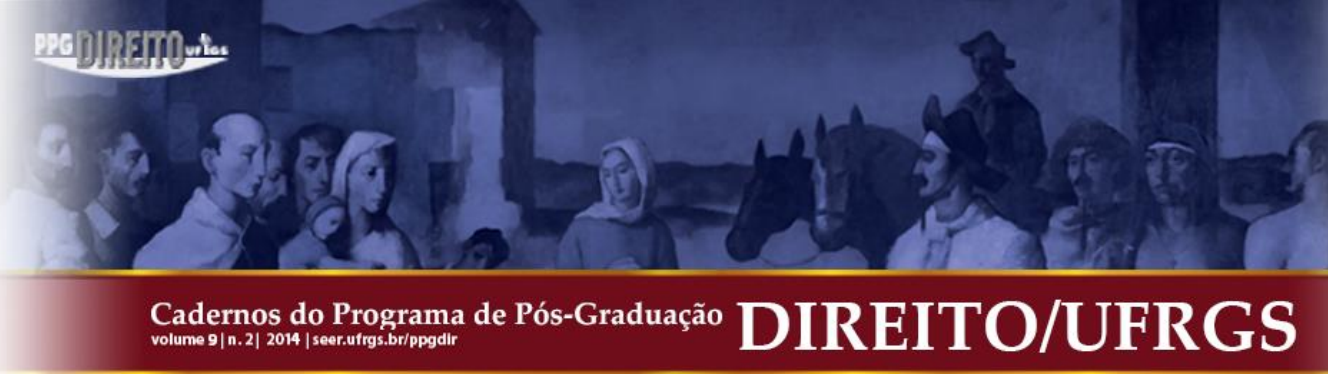

nização, sendo particularmente importante, no caso do Mercosul, caso considerada sua vocação de constituir-se em um polo de atração dos países sul-americanos. As consequências que derivam de tal ato para a entidade internacional e para o Estado que ingressa nela são determinantes para sua evolução e desenvolvimento futuro (JIMENEZ, 2010, pp. 53-58).

Estas, porém, não parecem ter sido as preocupações levadas em conta pelos chefes de Estado que tomaram a decisão de suspender o Paraguai e de, no mesmo ato, sancionar o ingresso da Venezuela como membro do bloco. Para Mata Diz, o ingresso da Venezuela como 'membro' pleno foi uma desconsideração dos textos e dos objetivos dos tratados e das normas do Mercosul, prejudicando a afirmação do Mercosul como bloco fundado no Estado Democrático de Direito e estruturado na defesa dos direitos e garantias juridicamente constituídos. Destaca que "o descumprimento das normas jurídicas estabelecidas pelos próprios Estados circunda de forma recorrente o processo de integração do Cone Sul, de modo que o episódio envolvendo a entrada da Venezuela contribui para uma corrosão ainda maior deste já delicado esquema de integração" (MATA DIZ, 2012, pp. 4-6).

A autora relembra que para pertencer ao Mercosul, é preciso que um país incorpore o chamado "acervo normativo" do bloco, que deveria ser observado pela Venezuela em vários temas, mas principalmente no que se refere ao programa de liberalização comercial e com a adoção da Tarifa Externa Comum (TEC). Passados sete anos da solicitação de adesão pela Venezuela, o país ainda não providenciou a adequação às exigências do bloco.

Ademais, observando-se o princípio da plena vigência das instituições democráticas como condição indispensável à existência e ao desenvolvimento do Mercosul e a cláusula democrática implícita, consolidada pelo Protocolo de Ushuaia e por seus documentos subsequentes, desaparecem quaisquer vestígios de coerência neste ingresso como ato contínuo da suspensão paraguaia (STURARO, 2012, p. 49).

Tendo em vista que a "Era Chávez" corresponde apenas parcialmente à definição mínima de democracia ${ }^{1}$ que se possa ter, não é admissível que este ingresso possa ser um passo direcionado à persecução de quaisquer dos objetivos eventualmente preconizados pelo bloco. Estando os direitos políticos e civis básicos comprometidos, de que constituem clara expressão a repressão à liberdade de expressão naquele país, mediante controle das emissoras de

\footnotetext{
${ }^{1}$ De acordo com Sturaro e Matsuno da Frota, citando Mainwaring, esta definição mínima compreende apenas os elementos cuja ausência não permita classificar o regime como democrático, sendo estas: (i) eleições competitivas, livres e limpas; (ii) sufrágio universal da população adulta; (iii) proteção aos direitos políticos e civis básicos; e (iv) governo efetivo dos representantes eleitos. (Op. cit., p. 48-49)
} 


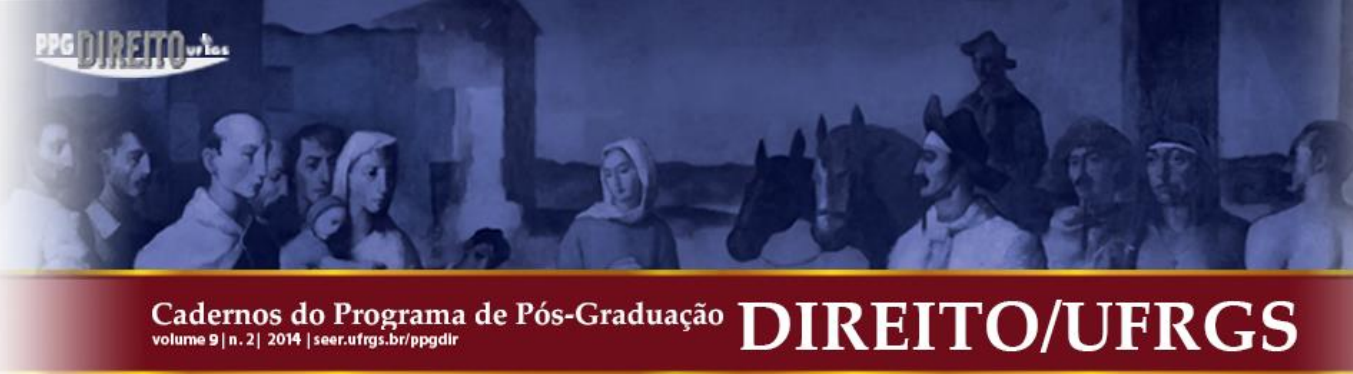

radio é televisão, e a limitação do direito de reunião, punida por leis que criminalizam o protesto político, a incompatibilidade com os valores democráticos pelos quais "prima(va)" o Mercosul é aviltada.

Mata Diz entende que o ato foi praticado pelos demais Estados-partes na ausência de um maior rigor na aplicação dos dispositivos e na interpretação dos fatos, a partir de entendimentos nitidamente ideológicos e nacionais, invocando-se a lógica de que decide por representar o povo, e que este fato legitimaria a decisão. A falta de um controle técnico e racional da decisão adotada fica igualmente exacerbada no episódio em apreço.

Tendo em vista que este episódio deu ensejo à aplicação do mecanismo de suspensão do Estado do Paraguai do Mercosul, seus termos, consequências e repercussão serão objeto de apreciação na etapa subsequente deste artigo.

\section{PROCESSO SANCIONATÓRIO DO PARAGUAI COMO FATOR DE DISPERSÃO NO MERCOSUL}

Foi de grande amplitude a repercussão que tiveram os fatos ocorridos em junho de 2012 no Paraguai na realidade integracionista do Mercosul. Os fatos ocorridos desencadearam séria crise política-institucional no seio do bloco, gerando questionamentos acerca da legitimidade de suas instituições, no que toca aos princípios e fundamentos sobre os quais se assenta, bem como em torno de seu referencial jurídico.

Como resposta ao episódio ocorrido no Paraguai, foi emitida Declaração dos Estados Partes do Mercosul e Estados Associados a respeito da ruptura da ordem democrática ocorrida no Paraguai, em 24 de junho de 2012, sendo posteriormente confirmada na XLIII Reunião Ordinária do Conselho do Mercado Comum (CMC), realizada em Mendoza (Argentina), em 29 de junho de 2012. Teve como fundamento o artigo 5, do Protocolo de Ushuaia sobre Compromisso Democrático, afirmando que que "toda ruptura da ordem democrática constitui um obstáculo inaceitável para a continuidade do processo de integração”. À mesma ocasião, ressalvou-se que as medidas tomadas não deveriam produzir prejuízo algum ao povo paraguaio.

Nesse sentido, as sanções aplicadas ao Paraguai em virtude da alegada "ruptura democrática", que teria sido causada pela prática do ato questionado, que estaria em desacordo com os valores do Mercosul, teriam sido sanções "leves" e políticas, mas não econômicas, segundo a presidente Cristina Kirchner, ainda que sua repercussão tenha-se revelado particularmente 


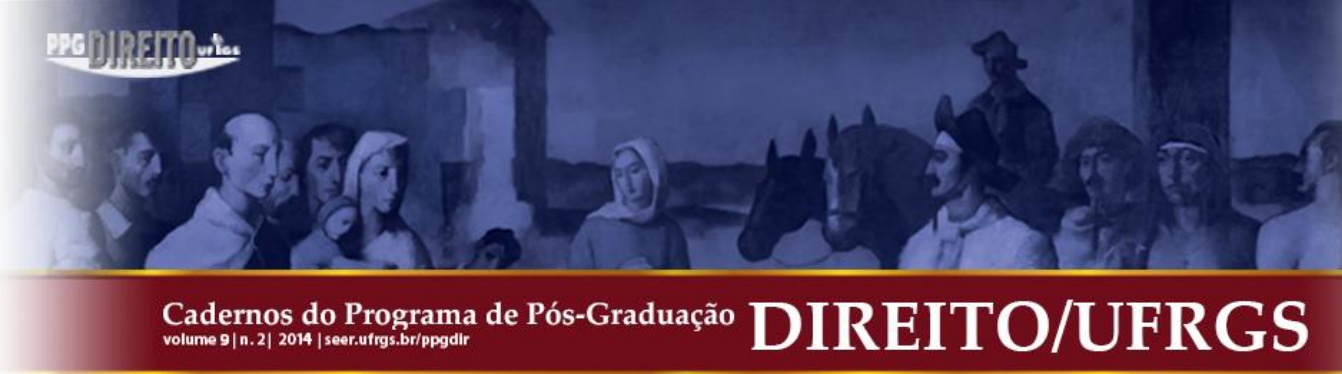

significativa neste campo. Os dados indicam que os Estados do Mercosul seriam os parceiros mais relevantes do Paraguai em termos numéricos, o qual seria nitidamente a parte mais prejudicada, por ser muito dependente dos outros parceiros do bloco (CARTA CAPITAL, 2012).

Giorgio Romano Schutte afirma que não seria interessante nesse momento colocar em prática sanções econômicas ao Paraguai, tais como a exclusão do Mercosul ou o corte da ajuda recebida por este país pelo FOCEM (Fundo de Convergência Estrutural do Mercosul), o que prejudicaria a população paraguaia. O que os Estados do bloco precisam é posicionar-se de forma efetiva, para prestigiar as democracias do grupo e evitar novos problemas semelhantes.

Contudo, o caráter dito "leve" é amplamente discutível, tendo em vista que esta suspensão acarretou outro evento amplamente contraditório: o ingresso da Venezuela no bloco. As críticas são tecidas principalmente em relação aos fundamentos jurídicos e democráticos em torno da legitimidade e adequação do procedimento aos tratados e protocolos do bloco.

Para o Prof. Fernando Sarti, da Unicamp, a suspensão do Paraguai aporta danos a todas as partes do bloco. Sua legitimidade fica profundamente afetada diante deste quadro, na medida em que todos seus fundamentos jurídicos estariam esvaziados em face da decisão arbitrária tomada pelos chefes de Estado, que teriam desrespeitado os documentos que estariam a reger a situação ocorrida, sobretudo o Tratado de Assunção, lei fundamental do bloco, que prevê a unanimidade entre os membros como requisito para admissão de novos membros no bloco (Artigo 20).

Ainda que a decisão de suspender ou não um Estado do bloco não seja de caráter jurídico, mas sim de cunho político, é indispensável que se dê de acordo com as previsões constantes dos tratados e protocolos que regem o bloco. Inafastável aqui, portanto, a análise do tema, porque intrinsecamente ligado ao evento da suspensão do Paraguai do Mercosul. O ingresso da Venezuela no bloco por via tão ou mais antidemocrática do que aquela por meio da qual se procedeu à suspensão do Paraguai ter-se-ia dado igualmente com amparo jurídico.

O fundamento legal apresentado pelos chefes de Estado quando da suspensão do Paraguai e ingresso da Venezuela assentou-se sobre o artigo 40, incisos II e III, do Protocolo de Ouro Preto. Na declaração emitida na mesma ocasião pelos presidentes de Brasil, Argentina e Uruguai, é invocado o Protocolo de Adesão assinado pelos quatro Estados-parte do Mercosul, com a Venezuela, em 2006, apontando que os dispositivos mencionados determinam os pro- 


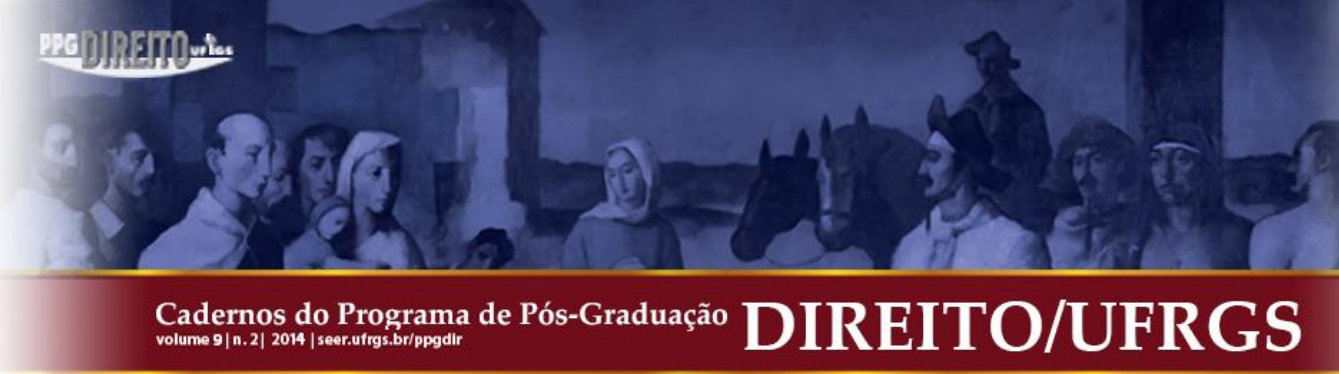

cedimentos para vigência simultânea nos Estados Partes das normas emanadas dos órgãos do Mercosul, após sua incorporação aos respectivos ordenamentos jurídicos internos.

A mesma norma legal era invocada também na primeira declaração, na parte decisória, onde se destaca que "enquanto durar a suspensão, o previsto no inciso III, do artigo 40, do Protocolo de Ouro Preto, produzir-se-á com a incorporação que realizarem Argentina, Brasil e Uruguai, nos termos do inciso II do referido artigo" (MERCOSUL, 2012). Estas disposições suscitam acalorado debate acerca da propriedade do mecanismo por meio do qual estes atos se perfizeram e em torno da extensão dos direitos e deveres que são mantidos ou não, durante a vigência da suspensão. Desta discussão depende a resposta de grande parte das questões inerentes ao estudo deste caso, ainda sem um deslinde concreto, em razão da recusa ao enfrentamento do tema pelo Tribunal Permanente de Revisão, como será exposto na sequência.

$\mathrm{Na}$ esteira do que dispôs o Informe Mercosul n. ${ }^{\circ} 17$, do Banco Interamericano de Desenvolvimento, editado em Dezembro de 2012 (p. 52), o único órgão legítimo para proceder ao controle da legalidade dos atos ocorridos e dos procedimentos adotados durante o processo impeachment do ex-presidente Fernando Lugo seria o poder judiciário paraguaio. No momento em que os Estados-parte do bloco aceitam um Estado como membro, aceitam também suas instituições e seu ordenamento jurídico de forma plena. Dessa forma, a aceitação do julgamento que teve lugar no Paraguai estaria de acordo com a Constituição daquele país, implicitamente aceita pelos Estados do Mercosul. Desta feita, não haveria que se falar em questionamento quanto a legitimidade do processo neste momento.

Nesse bojo, a cláusula democrática constante de Protocolo de Ushuaia, que foi invocada pelos demais chefes de Estado dos membros do Mercosul, se houvesse que por alguém ser invocada, que o fosse pelo povo paraguaio, eleitor daqueles poderes entre os quais se instaurara o entrave (HOFFMANN, 2009, p. 351). Desde há muito no Paraguai existe conflito entre os poderes executivo e legislativo. Isto ocorre em razão de o poder legislativo paraguaio ser detentor de ampla margem de manobra em razão de lhe caber a regulamentação do instrumento de impeachment, condicionando, assim, o executivo.

O Estado paraguaio, inconformado com a decisão dos chefes de Estado dos membros do Mercosul, encarada como arbitrária, levou o caso à apreciação do Tribunal Permanente de Revisão do Mercosul, requerendo a instauração do procedimento de urgência previsto pelo Protocolo de Olivos, que aperfeiçoou a estrutura institucional do bloco, instituída pelo Protocolo de Ouro Preto. Diante do impasse que tomou lugar no bloco, bem como das pressões da 


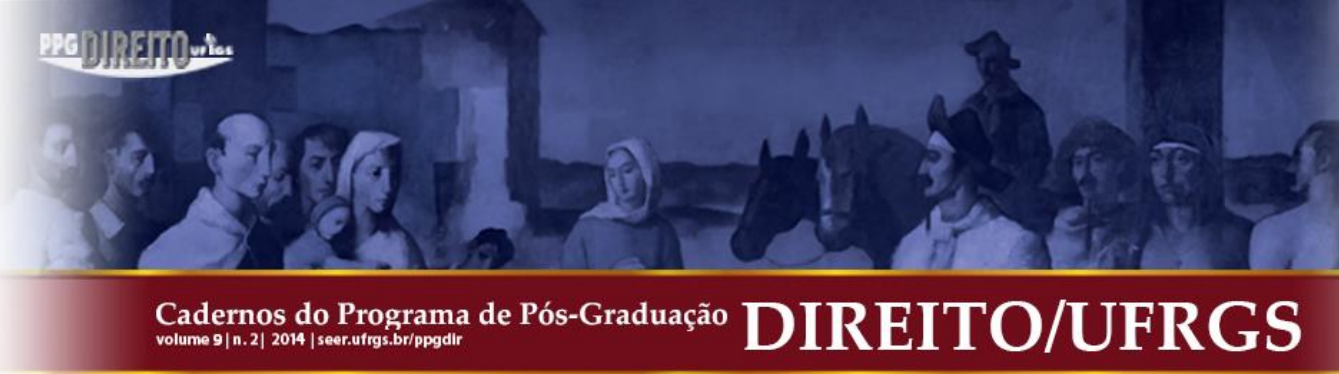

crítica tanto de repercussão interna como internacional, procedeu-se ao julgamento da demanda paraguaia com respeito ao regulamento e ao cronograma que regem esta instância (BANCO INTERAMERICANO DE DESENVOLVIMENTO, 2012, p. 49).

O TPR foi acionado com fulcro no artigo 24, do Protocolo de Olivos, que prevê mecanismo excepcional e de urgência, que estabelece o emprego de procedimentos especiais para solução de controvérsias surgidas de acordos emanados de reuniões de ministros do Mercosul que possam ocasionar danos irreparáveis às partes (DELUCA, 2011, p. 93). A admissão da causa pelo TPR depende do cumprimento de quatro requisitos de admissibilidade constantes do artigo 2, incisos, da Decisão n. ${ }^{\circ}$ 23/04 do Conselho Mercado Comum (MERCOSUL, 2004), os quais, segundo este Tribunal, não teriam sido cumpridos pela demanda apresentada.

Da análise da demanda, o TPR entendeu não ser competente para resolver a controvérsia proposta, recusando-se a adentrar no mérito da causa, sob alegação de não se tratar o objeto da demanda de questão comercial, mas de assunto de cunho meramente político. É claro que uma análise jurídica da situação atual do Mercosul no que se refere aos dois episódios examinados não pode estar completamente afastada da esfera política. No entanto, se a decisão política ocorre à margem das normas criadas e adotadas pelos próprios Estados, ela é não somente incoerente como também ilegal.

Afirma o Paraguai que o TPR seria a única instância à que poderia recorrer dentro do sistema de solução de controvérsias previsto no bojo do Mercosul, tendo em conta que ficariam as demais excluídas diante da condição de membro suspenso e os efeitos dela decorrentes que lhe cercavam, em razão das exigências procedimentais em torno de cada procedimento (TPR, 2012, § 16). Nessa situação, a negação do TPR em apreciar o caso poderia mesmo ser encarada como negação à prestação jurisdicional.

O centro do debate instaurado estaria entre dois posicionamentos: o primeiro, correspondente ao do entendimento defendido pela OEA, segundo o qual a causa se trataria de embate político entre os poderes executivo e legislativo paraguaios, cabendo a resolução exclusivamente à lei paraguaia, de acordo com sua Carta Constitucional; o segundo, consistente na opinião dos chefes de Estado dos demais Estados-parte do Mercosul, Argentina, Brasil e Uruguai, de acordo com o qual teria havido uma ruptura da ordem democrática, em razão do cerceamento de defesa do ex-presidente impedido e do desrespeito ao devido processo legal.

Dessa segunda hipótese decorre o argumento destes países em favor da legalidade e adequação da entrada da Venezuela como membro do bloco, como ato contínuo à suspensão 


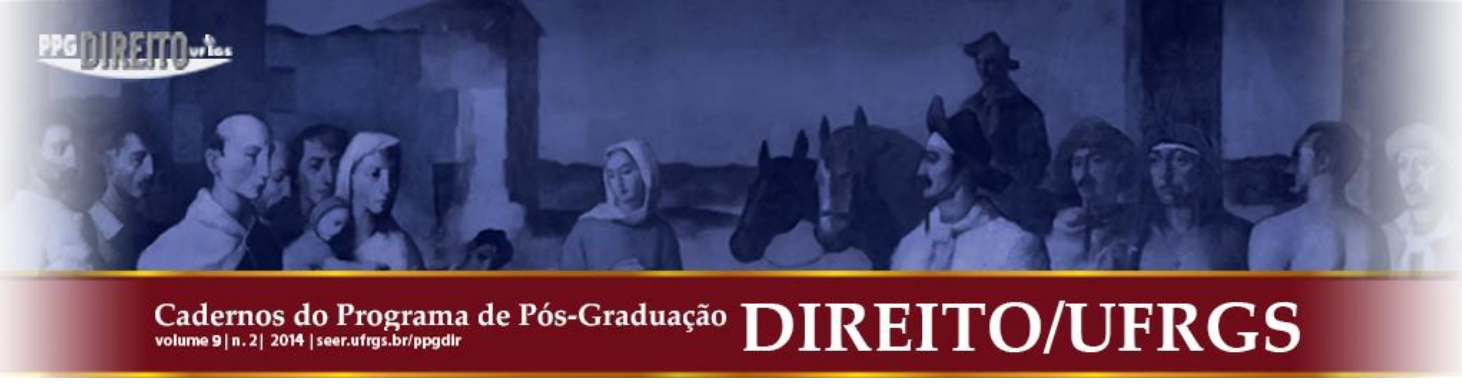

do Paraguai. De acordo com este entendimento, o país que não estivesse sob a égide de um governo democrático não poderia opinar em questão como aquela relativa à adesão de novos Estados ao bloco. Este ato, ao contrário, tornaria ineficaz o protocolo de Ushuaia, que traz em seu bojo o compromisso com a ordem democrática, já que estaria sendo aceita a participação no processo de governo conduzido em condições adversas.

Sustentou ainda o Paraguai que a suspensão referida não se instrumentalizou mediante norma emanada dos órgãos enunciados no Protocolo de Ouro Preto nem por meio da aplicação das fontes jurídicas enunciadas no artigo 41, do Protocolo de Ouro Preto. Questiona a legitimidade dos chefes de Estado para adotar decisões obrigatórias, tendo em vista que as Reuniões de Cúpula presidenciais não constituem e nem integram os órgãos do Mercosul, de maneira que suas decisões não se ajustariam à normativa da organização (TPR, 2012, § 16).

Nessa medida, o Tratado de Assunção teria sido violado em razão do desrespeito ao requisito de unanimidade constante do seu artigo 20, n. 3, para a admissão de novos membros, tendo sido igualmente desrespeitados o artigo 40, do Protocolo de Ouro Preto, que trata da simultaneidade de vigência nos Estados-parte das normas emanadas dos órgãos do Mercosul (inciso III), e a Convenção de Viena sobre o Direito dos Tratados, por consequência. ${ }^{2}$

A legitimidade do instrumento pelo qual se operou tanto a suspensão do Paraguai como a incorporação da Venezuela ao bloco é questionada. De acordo com as alegações paraguaias, uma decisão presidencial não teria o condão de perfazer tais atos. As decisões objeto da demanda padeceriam de falta de motivação, carecendo, portanto, de validade jurídica, dando origem, assim, à responsabilidade internacional pelo descumprimento dos documentos do Mercosul (TA, POP e PU), bem como de outras normas e princípios de Direito Internacional.

Em sede de contestação, Brasil, Argentina e Uruguai alegam, em sede preliminar, incompetência ratione materiae, em razão da natureza política da decisão atacada no marco do Protocolo de Ushuaia e da natureza comercial do sistema de solução de controvérsias do Mercosul. Alegam os demandados, subsidiariamente, que o Protocolo de Olivos não seria aplicável para dirimir conflitos emergentes da aplicação do Protocolo de Ushuaia. Afirmam ainda ter sido inadequada a via eleita e também a incompetência do TPR devido à falta de consentimento para o exercício da competência originária do artigo 23, do Protocolo de Olivos.

\footnotetext{
${ }^{2}$ Sob este argumento, o caso poderia ser levado a conhecimento perante a Corte Internacional de Justiça em Haia, o que, contudo, foi apenas ventilado, mas não se consumou.
} 


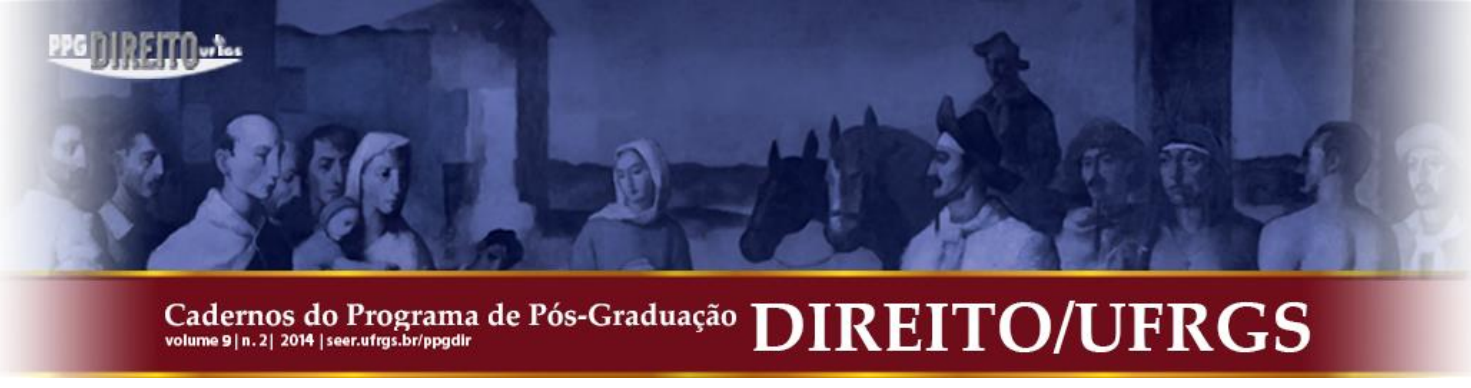

No mérito, alegaram que não há exigências específicas quanto a forma do procedimento previsto no artigo 5, do Protocolo de Ushuaia. Nada dispondo acerca do assunto, quanto a rito solene ou a demais formalidades, as medidas adotadas da forma que o foram, ou seja, por decisão presidencial e de competência dos Chefes de Estado, seriam, além de lícitas e legítimas, estritamente políticas (alegação da qual se discorda, tendo em vista a séria repercussão econômica para o país em virtude de sua suspensão do bloco), o que afastaria ainda a necessidade de realização de um processo com contraditório para que fosse proferida.

No que toca à alegada violação do artigo 20, com relação à forma da aprovação da solicitação de adesão da Venezuela e à declaração de incorporação do novo membro, afirmam os demandados que a primeira decisão, prevista no artigo 20, do Tratado de Assunção, requereria unanimidade, que fica, contudo, prejudicada, em razão de a participação do Paraguai, na condição de suspenso, tornar ineficaz o protocolo de Ushuaia, ${ }^{3}$ "suprindo" o requisito de unanimidade. Quanto à segunda alegação, afirma-se de caráter declaratório, dispensando, portanto, a unanimidade, e que o Protocolo de Adesão da Venezuela entraria em vigor 30 dias após a data de depósito do último instrumento de ratificação dos Estados partes não suspensos, de modo que o Paraguai, suspenso, não contaria para tal fim.

Caso não acolhidas as preliminares, pugnaram pela improcedência da apresentação, seja no que se refere ao pedido de cancelamento da suspensão do Paraguai, seja quanto ao pedido de suspensão dos efeitos da Declaração sobre a Incorporação da República Bolivariana da Venezuela ao Mercosul.

Diante dos argumentos apresentados por ambas as partes, entende-se que não ficou suprido o requisito da unanimidade, em razão da suspensão do Estado do Paraguai. O país era o depositário do Protocolo de Adesão da Venezuela, e de sua ratificação dependia o ingresso desta no bloco. Na há que se falar em suprimento quando o texto é claro. Descabida igualmente a alegação de que seria de caráter declaratório o instrumento de incorporação, uma vez que ausente previsão deste procedimento para adesão de novos membros no corpo normativo do bloco. Nitidamente, foi feita foi uma manobra para satisfação de interesses políticos.

Ainda que não tenha admitido a análise do caso em seu mérito, o TPR avocou a consideração do pedido formulado, entendendo que a suspensão estabelecida em relação à participação de um Estado-parte nos órgãos do Mercosul não afeta seu direito de recorrer ao sistema

\footnotetext{
${ }^{3}$ Em razão da permissão de participação de Estado não democrático no processo de decisão (artigo 5, Protocolo de Ushuaia)
} 


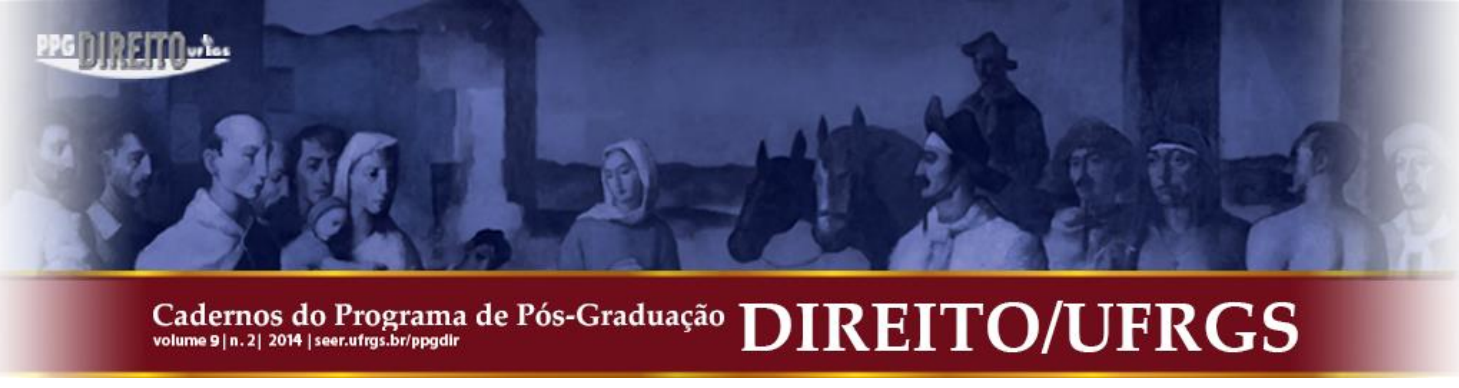

de solução de controvérsias estabelecido no Protocolo de Olivos. O Paraguai alega, em sua representação, que a gravidade das medidas adotadas na $43^{\mathrm{a}}$ Reunião de Cúpula de Presidentes causa dano irreparável por impedirem o exercício de seus direitos soberanos e inalienáveis como Estado fundador do Mercosul (TPR, 2012, § 16).

Com base nos argumentos expostos pelas partes (e também em razão da potencial discussão política que qualquer emissão de opinião causaria), o TPR declarou-se incompetente para a apreciação do caso em razão da matéria, afirmando ausentes, por unanimidade, os requisitos exigidos à admissibilidade do procedimento excepcional de urgência regulamentado pela Decisão 23/04. Por maioria, ainda decidiu que, nas condições da demanda, era inadmissível a intervenção direta do TPR sem consentimento expresso dos demais Estados-parte, sendo, pela mesma razão, inadmissível a concessão das medidas solicitadas na demanda.

Não tendo sido examinado o mérito, muitas questões essenciais ao deslinde do feito deixaram de ser apreciadas. A definição de termos indispensáveis, tais como o conceito de "membro suspenso", bem como o alcance desta condição para definição dos direitos e deveres mantidos ou não durante este estado, são essenciais para determinação da legitimidade da decisão de incorporação da Venezuela como membro, na mesma ocasião da suspensão. Não se fecham, contudo, as portas para apreciação da demanda por outras vias.

A resposta para estas questões ficaria para a apreciação de recursos eventualmente interpostos pelo Paraguai a tribunais internacionais, tais como a Corte Internacional de Justiça, em Haia, cuja opção foi inclusive aventada, porém até então não empreendida. A resposta não se encontra tampouco no principal modelo de integração regional fundada sobre um tratado constitutivo semelhante, e até mais abrangente, que é o caso da União Europeia. Naquele âmbito, o procedimento que envolve a prevenção e a suspensão de um Estado-membro em caso de desrespeito aos princípios sobre os quais se funda a União nunca foi antes empregue, como visto na primeira parte deste artigo.

A Convenção de Viena sobre o Direito dos Tratados, de 1969, poderia aportar contribuições, com relação à discussão em torno de ter ou não havido violação do Tratado de Assunção e dos Protocolos adicionais que regem o Mercosul em todo este episódio. Entretanto, o mérito, como foi dito, não foi alvo de apreciação ainda, e antes que o seja, inúmeras questões políticas deverão ser consideradas.

Neste caso específico, ainda que tenha havido recurso por parte do Paraguai ao sistema de solução de controvérsias do bloco, este, instado a se manifestar, considerou que o procedi- 


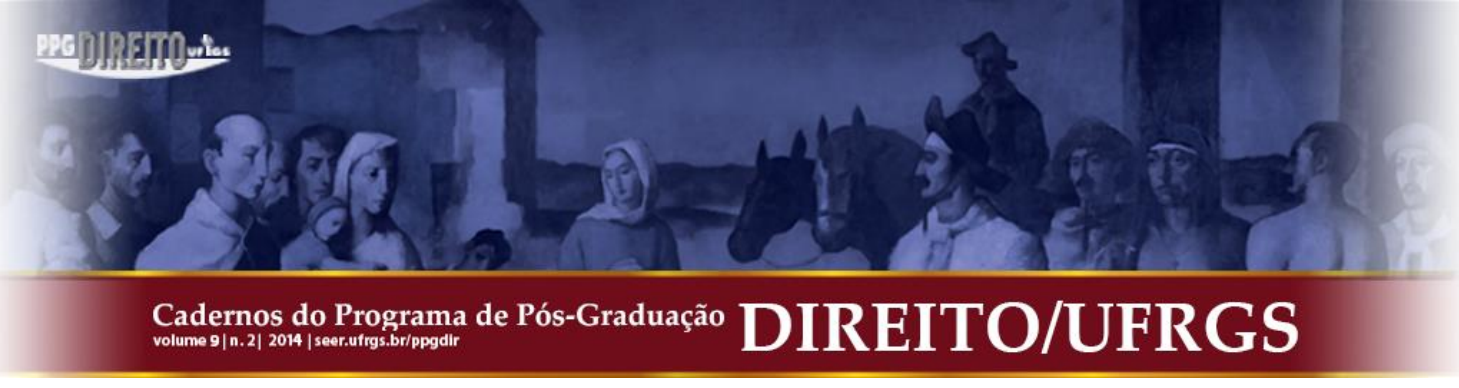

mento excepcional de urgência solicitado pelo Paraguai não era aplicável neste caso, em uma nítida tentativa de lavar as mãos, evitando posicionar-se acerca do ocorrido. Tal atitude é inaceitável em se tratando da mais alta instância jurídica de uma organização internacional de vocação regional. Desde que judicializada a relação, esta deve ser objeto de decisão exclusivamente pelo órgão jurídico competente, não havendo que se falar em decisão política, portanto.

A corte de revisão do Mercosul, no caso em apreço, teria o dever de se manifestar, não apenas em razão de ter a competência para tanto e de ter o dever de se manifestar acerca da legalidade dos atos praticados no âmbito do bloco, mas pelo essencial papel que desempenham os tribunais em um projeto integracionista: sua atividade não deve ser meramente revisional, pertencendo também a sua esfera a promoção do diálogo entre as cortes e tribunais constitucionais (KEGEL, 2012).

Diante da situação, em manifestação acerca do assunto, o presidente do Uruguai, José Mujica afirmou estar-se vivenciando uma "crise institucional" no Mercosul. Mujica reivindicou que o bloco realize mudanças de forma a reequilibrar as discrepâncias políticas e comerciais entre os Estados-partes: Uruguai, Argentina, Brasil, Paraguai (que está suspenso) e a recém-incorporada Venezuela. Afirma o presidente que "[é] preciso fazer um balanço da realidade, aquele Mercosul dos anos 90, nascido em pleno neoliberalismo, mudou. Hoje, temos uma crise institucional e serão necessárias mudanças para flexibilizá-lo” (BBC Brasil, 2012).

Em nota, o secretário-geral da OEA, José Miguel Insulza lamentou que já tenham sido "várias as ocasiões (na América Latina) que em alguns países, apegando-se ao pé da letra da lei, violam-se princípios democráticos que devem ter vigência universal." (UCHOA, 2012)

A ministra da defesa do Paraguai, María Liz García, afirmou, em 20 de agosto, que: “[la] UNASUR, evidentemente ya no genera ninguna confianza al menos al Paraguay. Es el problema cuando se desvirtúan los principios, se traspolan los valores, se viola el principio de la autodeterminación de los pueblos ", referindo-se à sanção sofrida pelo país em razão do acordo entre os demais países em realizar o "bloqueio econômico" ao novo governo não reconhecido de Frederico Franco (La Red 21, 2012).

Sem dúvida, o principal impacto a ser sofrido pelo bloco, com relação às decisões recentemente adotadas, foi o da confirmação de que o processo de integração, após tantos contratempos, entre avanços e retrocessos, continua sendo palco de interesses particulares de al- 


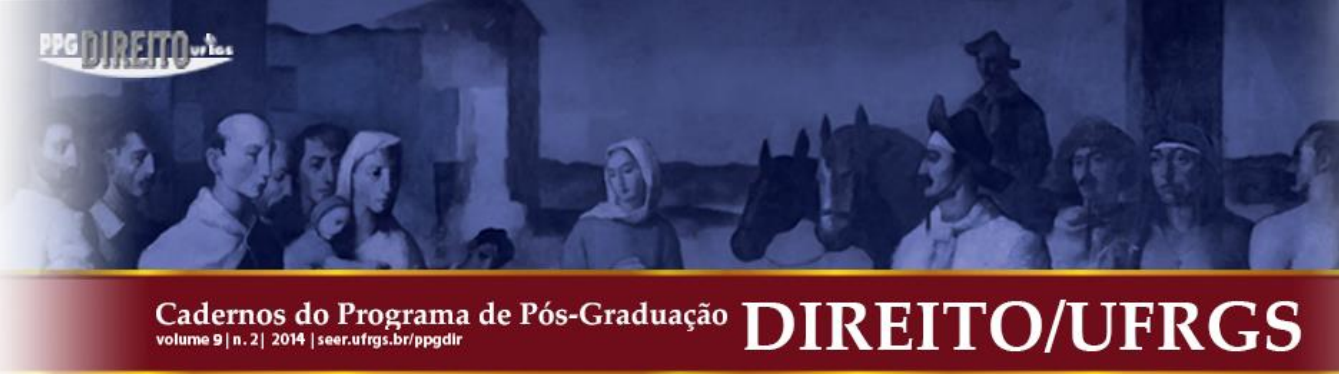

guns Estados. Nem mesmo as políticas econômicas do grupo, finalidade precípua para a qual foi constituído, convergem (FERRERES, 2012, p. 12-13).

Ao desconsiderarem o sistema jurídico que os cerca, as lideranças políticas de Argentina, Brasil e Uruguai violaram a ordem democrática, uma vez que esta se encontra estreitamente vinculada ao Estado de Direito. Portanto, resta-nos repetir a questão: haverá suspensão provisória dos demais Estados, inclusive da Venezuela e do Brasil, dado que esses países também descumpriram a ordem democrática?

\section{CONSIDERAÇÕES FINAIS}

Ao contrário do que se verifica na União Europeia, que instituiu um verdadeiro sistema articulado e complexo fundado sobre seus tratados para a suspensão de um Estado-membro do bloco, no caso de violação ou por ameaça de violação dos princípios fundamentais do bloco, ressaltando o caráter democrático do procedimento de suspensão de um Estado da União, o Mercosul apresenta total ausência de um mecanismo de controle da legalidade dos atos das instituições do bloco, o que reflete a desordem instaurada e explica inúmeras perguntas sem resposta. No exemplo europeu, é reconhecida a verdadeira dimensão desta decisão, cujas consequências representam profunda ingerência na esfera interna do Estado penalizado.

Há quem diga que o ocorrido no Paraguai em 2012 teria sido uma institucionalização de um golpe de Estado pela oposição paraguaia: o processo inteiro ocorrido no âmbito interno daquele Estado-parte foi realizado de acordo com as normas e com a constituição paraguaia, como observado. No entanto, uma vez aceito o Estado no bloco, não se aceita apenas seu executivo, seu legislativo, ou apenas seu judiciário, mas o conjunto. Foi aceito o modelo paraguaio de regulamentar o impeachment pelo legislativo, tendo sido igualmente aceitas as instituições que o conduzem.

Ainda que julgado demasiadamente célere ou mesmo injusto e, é claro, antidemocrático, o procedimento de suspensão adotado pelos líderes do Mercosul veio em hora errada e pela via errada. Teria sido de grande auxílio, neste bojo, a existência de previsão de um mecanismo como aquele instituído na União Europeia, por exemplo, que dispõe de mecanismo para prevenção da ocorrência de violação grave, e também um rigor maior para a adoção das medidas de suspensão. O modelo reflete a importância da rigidez deste procedimento que, em razão de ser puramente político, deve-se ater às exigências impostas. 


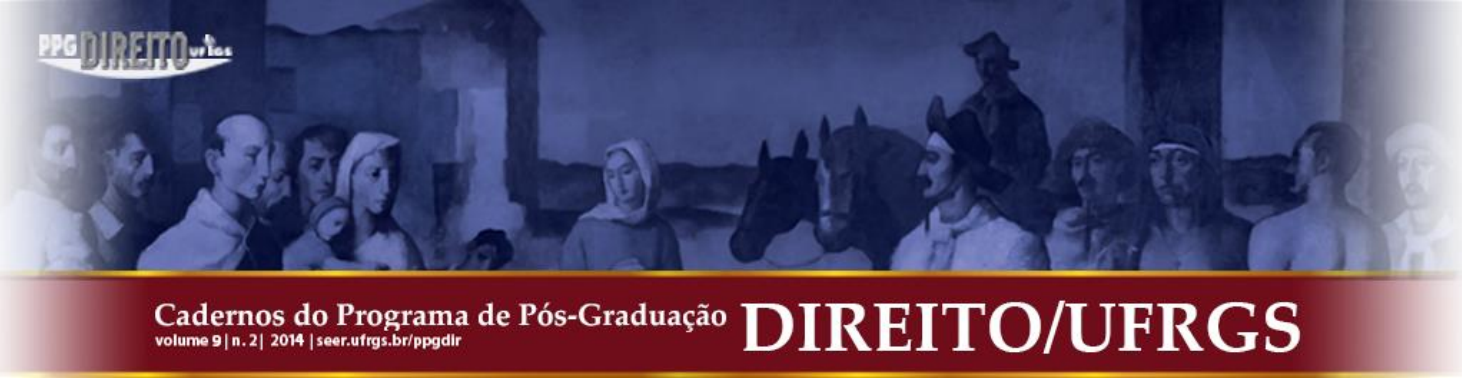

O que ocorreu no Mercosul foi um retrato da sobreposição de interesses econômicos ao marco jurídico do bloco. Tentou-se manejar os Protocolos e Tratados existentes, de modo a promover a entrada da Venezuela, passando-se, assim, por cima da anuência paraguaia, única ratificação faltante do instrumento de adesão da Venezuela ao bloco (VALIM, 2012). A medida para promover seu ingresso forçado, e então satisfazer os interesses econômicos em jogo, nomeadamente em torno do petróleo Venezuelano e da atração do comércio deste com o bloco, revelou-se no mínimo tortuosa, aniquilando com qualquer marco jurídico que pudesse existir no bloco. Fica claro o emprego de dois pesos e duas medidas.

O ocorrido não pode ser analisado isoladamente, no caso em apreço, tendo em vista que não envolve questões apenas jurídicas, apenas políticas ou apenas econômicas, adquirindo, ao contrário, caráter sistêmico, o que demanda uma análise também no plano racional. Assim, embora tenha havido correção sob algum prisma, seja no procedimento de suspensão do Paraguai, seja no procedimento de adesão da Venezuela, reluz a manobra realizada para satisfação de interesses que fazem cair por terra, novamente, todos os princípios sobre os quais se assenta o bloco, fundamentalmente a ordem democrática.

Do exposto, o mínimo que se pode concluir é que os atos praticados pelos Chefes de Estado do Mercosul são incompatíveis com o que se espera de um bloco regional, que tem por pressupostos a democracia e o respeito aos direitos humanos e fundamentais. É no mínimo incompreensível suspender-se um Estado-parte sob alegação de ruptura da ordem democrática, em razão um procedimento que nem sequer vai de encontro ao documento supremo do Estado em que teve lugar, que seria a Constituição paraguaia, e a admissão de outro, cuja tradição é essencialmente antidemocrática, que prega o "anti-imperialismo" e que reconhecidamente viola direitos humanos e fundamentais em sua ordem interna.

Por este prisma sim, é evidente a ruptura da ordem democrática Venezuelana, que, por seu turno, acaba de ingressar como membro deste agregado institucional que é o Mercosul. A impressão que fica é a de contradição, quando analisados ambos os acontecimentos em conjunto, comprometendo a credibilidade do regime. Quanto aos argumentos ventilados de que se estaria primando pela finalidade precípua do bloco, do desenvolvimento econômico e a da promoção dos interesses de seus Estados-partes, todo e qualquer ato perde sua legitimidade já que foram simplesmente desrespeitados os fundamentos e princípios sobre os quais se apoia, evidenciando a total desconsideração do marco jurídico do bloco. 


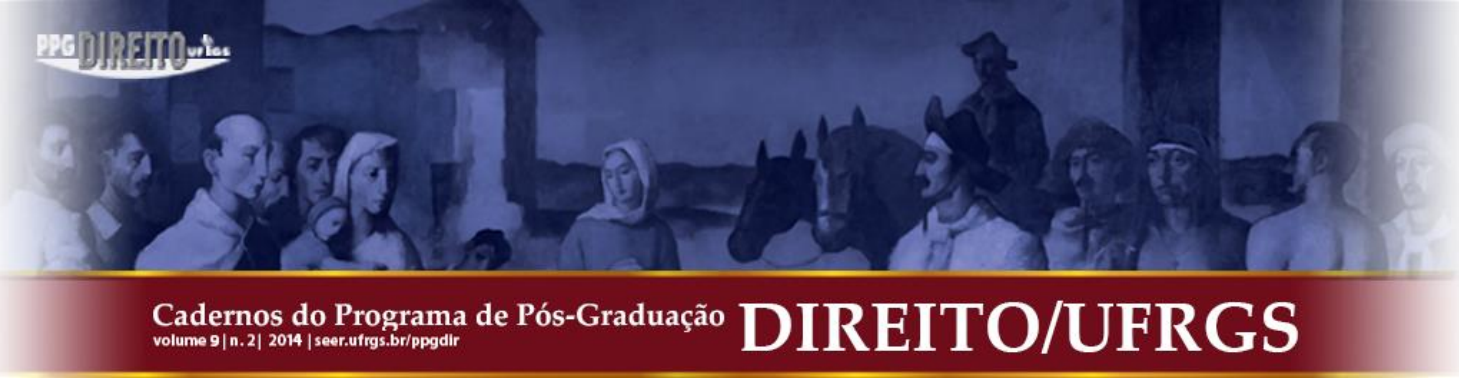

Deste modo, ainda que aceita a coesão jurídica ou a coerência do procedimento de suspensão do Estado do Paraguai com o conteúdo dos tratados e protocolos que regem o bloco, não se pode olvidar a incoerência da admissão da Venezuela ao grupo, de forma simultânea (inclusive pela mesma decisão que suspendeu o outro país), tendo em conta o seu histórico. A nítida forma de burla pelos demais chefes de Estado ganha contornos evidentes, diante da admissão da Venezuela como ato contínuo à suspensão paraguaia, e exalta a perda de legitimidade do bloco, assim como de qualquer menção integracionista que pudesse ser invocada apoiando-se sobre os pilares e princípios propostos nos tratados.

O Mercosul, já desacreditado e enfraquecido após a constatação de profundas incoerências entre discurso e atuação, destitui também agora o marco jurídico capaz ainda de sustentar o bloco. Ainda que se considere um projeto quase romântico aquele da integração mais profunda no continente latino-americano, esvaem-se agora as demais esperanças diante da quebra de um dos elos que parecia dar certo: o objetivo de consolidação e manutenção dos valores democráticos no seio do bloco.

A efetividade dessa cláusula democrática passa a ser questionável, pois, sabe-se, o valor dos documentos no Mercosul não tem o condão de se sobrepor às pressões políticas da região. Ainda que a cláusula possa ser invocada neste âmbito como mantenedora e garantidora da democracia do bloco, entende-se que sua aplicação somente será plena quando seja invocada pela sociedade paraguaia, e não apenas pelos presidentes de outros Estados-partes.

Nessa esteira, ainda que a adesão da Venezuela se perfectibilize e se regularize por esta via, analistas apontam que permanecem incontáveis duvidas acerca da capacidade de a Venezuela incorporar e implementar, dentro do prazo estimado, todas as normativas necessárias para que se torne membro pleno do bloco. Quatro anos, conforme estipulado no decreto presidencial que promulgou a adesão do país ao bloco, não são suficientes para implementar as mudanças com as quais a Venezuela já se havia comprometido em 2006, para implementação até janeiro de 2012, e que ainda não o fez desde então (TOKARNIA, 2013, p. 44).

O momento de crise institucional leva-nos a comparar este bloco com o da União Europeia, que, apesar de não ter ainda posto em pratica seu recurso de suspensão, reflete a segurança e os verdadeiros fundamentos sobre os quais deve se assentar um bloco de integração. Todo esse contexto leva-nos a questionar se não seria o Mercosul uma estrutura desgastada e desprovida de núcleo essencial, sem aptidão para prover um sustentáculo firme à persecução 


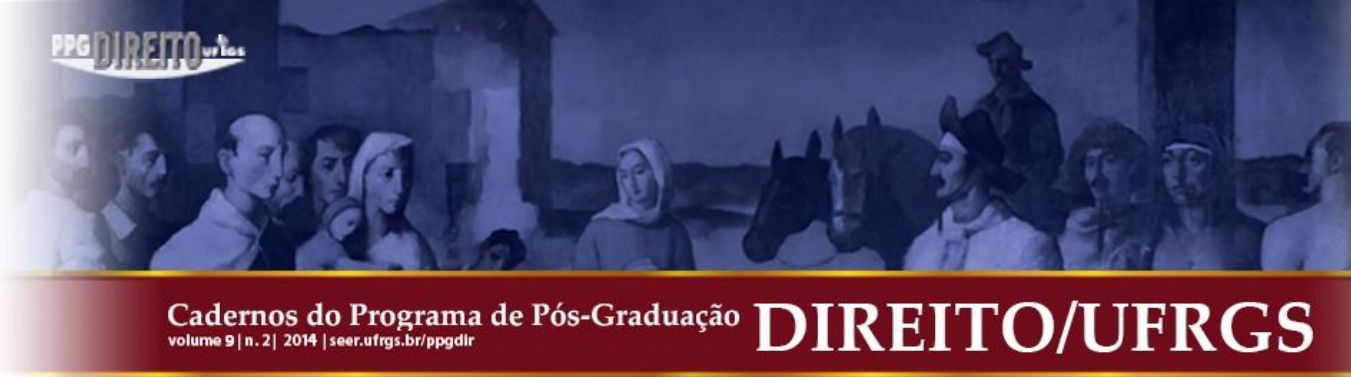

de seus objetivos econômicos e sociais por meio da promoção de programas de auxilio aos Estados mais necessitados.

Trata-se do momento propicio para repensar a estrutura existente e buscar uma congruência, se é que ainda possível, com os verdadeiros interesses que permeiam as relações entre seus Estados-partes.

\section{REFERÊNCIAS}

BANCO Interamericano de Desenvolvimento. Informe MERCOSUL $N^{o} 17$. Setor de Integração e Comércio - Instituto para integração da América Latina e do Caribe. Buenos Aires: BID-INTAL, 2012.

BBC BRASIL. Notícia veiculada em 15 ago. 2012. Para presidente do Uruguai, Mercosul está vivendo "crise constitucional". Disponível em: <http://www.bbc.co.uk/portuguese/ultimas_noticias/2012/08/120815_uruguai_mujica_lgb_rn. shtml>. Acesso em: 03 set. 2012.

BERNALETTE, Oscar Hernández. O tortuoso ingresso da Venezuela ao Mercosul. Pontes Informações e análises sobre comércio e desenvolvimento sustentável, Mercosul: crise ou renovação?, Genebra, v. 8, n. 5, pp. 7-10, ago. 2012. Disponível em: <http://ictsd.org/downloads/pontes/pontes8-5.pdf>. Acesso em 01 fev. 2013.

BONIS, Gabriel. Expulsão do Mercosul traria grande impacto ao Paraguai. Carta Capital. Notícia veiculada em 29 jun. 2012. Disponível em: < http://www.cartacapital.com.br/internacional/expulsao-do-mercosul-traria-grande-impacto-aoparaguai/>. Acesso em 01 fev. 2013.

BORGES, José Souto Maior. Curso de Direito Comunitário. São Paulo: Saraiva, 2009.

CARTA CAPITAL. Notícia veiculada em 29 jun. 2012. Paraguai é suspenso do Mercosul e Venezuela vira membro-pleno. Disponível em: $<$ http://www.cartacapital.com.br/internacional/paraguai-e-suspenso-do-mercosul-e-venezuelavira-membro-pleno/>. Acesso em 01 fev. 2013.

DELUCA, Santiago. El procedimento ante el Tribunal Permanente de Revisión del Mercosur. In: DEL POZO, Carlos Molina; PIZZOLO, Calogero (coord.). La administración de justicia 


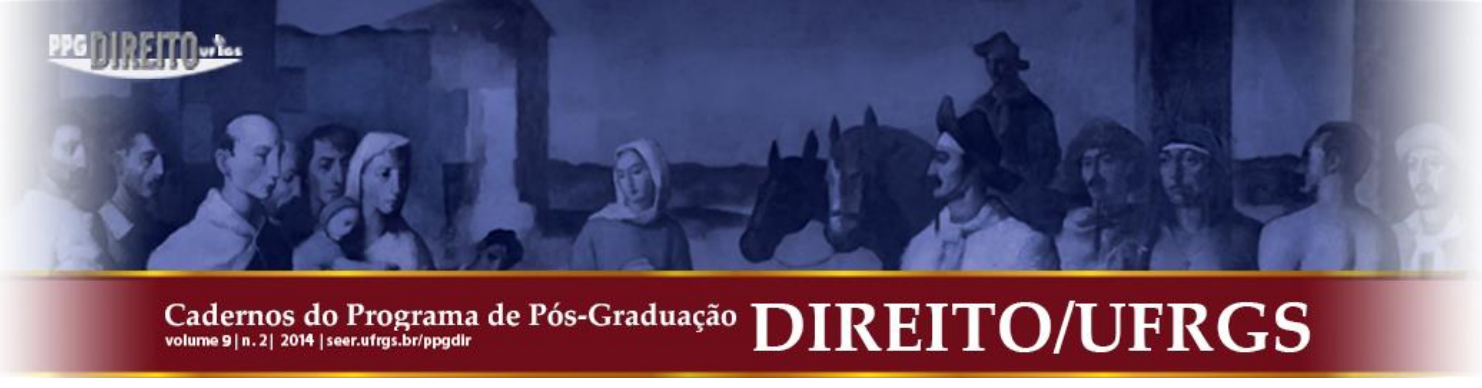

em la Unión Europea y el Mercosur: um análisis para su fortalecimento. Eudeba: Buenos Aires, 2011.

FERRERES, Orlando. Mercosul: todos os benefícios para o Brasil. Pontes - Informações e análises sobre comércio e desenvolvimento sustentável, Mercosul: crise ou renovação?, Genebra, v. 8, n. 5, pp. 11-13, 2012. Disponível em: <http://ictsd.org/downloads/pontes/pontes85.pdf>. Acesso em 03 fev. 2013.

KEGEL, Patrícia. A interconexão dos sistemas jurídicos através dos Direitos Humanos e a posição das Constituições Nacionais. Congresso internacional: As integrações regionais e os indivíduos. 3 e 4 de dezembro de 2012. Porto Alegre: Faculdade de Direito da Universidade Federal do Rio Grande do Sul, 2012.

HOFFMANN, Andrea Ribeiro. Democracia e integración regional: el caso del Mercosur. In: BOGDANDY, Armin Von; ARROYO, César Landa; ANTONIAZZI, Mariela Morales (eds.). Integración suramericana a través del Derecho? Un análisis interdisciplinario y multifocal. 197, Cuadernos y Debates. Centro de Estudios Políticos y Constitucionales - Max Planck Institut, 2009. pp. 339-354.

JIMENEZ, Martha Lucía Olivar. La adhésion de nuevos miembros al Mercosur : una cuestión fundamental para la evolución de la organización. In: FLAESCH-MOUGIN, Catherine LEBULLENGER, Joël. Regards croisés sur les intégrations régionales : Europe, Amériques, Afrique - Collection Rencontres Européens. Bruxelles: Bruylant, 2010, pp. 53-88.

LA RED 21. Notícia veiculada em 20 ago. 2012. Paraguay al Mercosur: "tenemos que prepararnos para la guerra”. Disponível em: <http://www.lr21.com.uy/mundo/1054973paraguay-al-mercosur-\%E2\%80\%9Ctenemos-que-prepararnos-para-la-guerra\%E2\%80\%9D>. Acesso em: 03 set. 2012.

MATA DIZ, Jamile Bergamaschine. A adesão da Venezuela ao Mercosul e a suspensão do Paraguai: considerações sobre um pragmatismo burlesco. Pontes - Informações e análises sobre comércio e desenvolvimento sustentável, Mercosul: crise ou renovação?, Genebra, v. 8, n. 5. pp. 4-6, 2012. Disponível em: 〈http://ictsd.org/downloads/pontes/pontes8-5.pdf〉. Acesso em 03 fev. 2013.

MERCOSUL. Declaração Presidencial da Segunda Cúpula Presidencial do Mercosul. Mendoza, 2012. Disponível em: <www.mercosul.gov.br>. Acesso em 01 fev. 2013. 


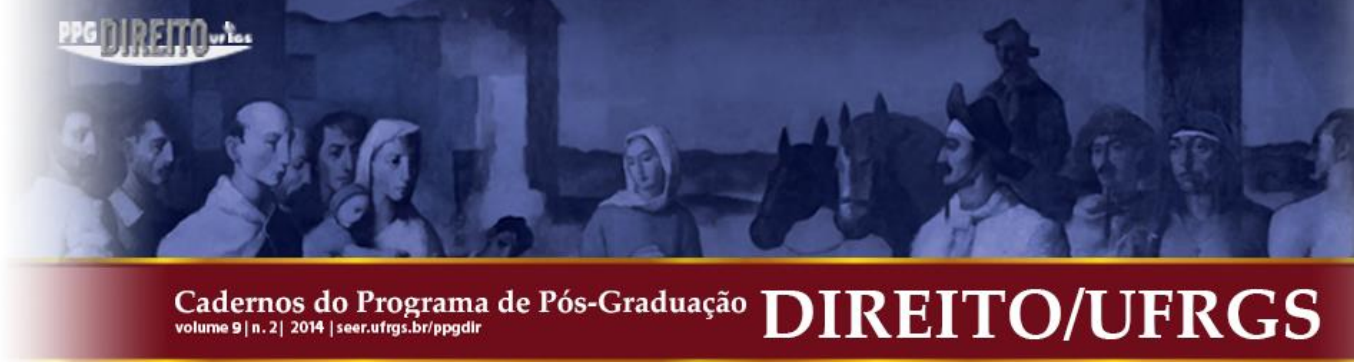

Comum do Sul (Mercosul) e à incorporação da Venezuela como membro pleno. Disponível em: <http://www.tprmercosur.org/pt/docum/laudos/Laudo_01_2012_pt.pdf>. Acesso em 01 fev. 2013.

UCHOA, Pablo. Sem consenso e descolada do Mercosul, OEA volta a discutir Paraguai. Notícia veiculada em 09.07.2012 por BBC Brasil. Disponível em: <http://www.bbc.co.uk/portuguese/noticias/2012/06/120623_oea_paraguai_pu.shtml>. Acesso em: 03 set. 2012.

VALIM, Rodrigo. A influência da integração regional na defesa dos Direitos Humanos. Congresso internacional: As integrações regionais e os indivíduos. 3 e 4 de dezembro de 2012. Porto Alegre: Faculdade de Direito da Universidade Federal do Rio Grande do Sul, 2012.

Submissão: 10/06/2013 Aceito para Publicação: 14/08/2013 